http://journal.nafo.int

J. Northw. Atl. Fish. Sci., Vol. 1: 55-64

\title{
Atlantic Salmon Caught in the Irminger Sea and at East Greenland
}

\author{
J. Mфller Jensen \\ Grønlands Fiskeriunders $\emptyset$ gelser \\ DK 2920 Charlottenlund, Denmark \\ and \\ W. H. Lear \\ Department of Fisheries and Oceans, Research and Resource Services \\ P. O. Box 5667, St. John's, Newfoundland, Canada A1C 5X1
}

\begin{abstract}
Research vessel drift-netting in the Irminger Sea during the summers of 1966 and 1973-75 yielded 80 salmon, of which 77 were one-sea winter fish, 2 were two-sea-winter fish, and 1 was a previous spawner. The proportions of salmon of North American and European origin caught in 1973-75, estimated by discriminant functions based on scale characters, were 21 and $79 \%$ respectively. The average smolt age of North American salmon ( $3.4 \mathrm{yr}$ ) was significantly higher than that of European salmon (1.9 yr), but the average length of the former $(62.9 \mathrm{~cm})$ was lower than that of the latter $(67.8 \mathrm{~cm})$. The recapture at East Greenland of adult salmon tagged as smolts in North American and European rivers also indicates a mixed population in the area. The size of the feeding population could not be estimated from the available data, but catch-per-unit-effort data indicate that it is probably much smaller than in West Greenland waters.
\end{abstract}

\section{Introduction}

Nielsen (1961) reported that Atlantic salmon, Salmo salar L., had been repeatedly taken near Angmagssalik ( $\left.65^{\circ} 36^{\prime} \mathrm{N}, 37^{\circ} 38^{\prime} \mathrm{W}\right)$, East Greenland, in the mid and late 1950's, and that in the autumn of 1957 many salmon were taken by jigger during fishing for cod at Skjoldungen $\left(63^{\circ} 14^{\prime} \mathrm{N}, 41^{\circ} 27^{\prime} \mathrm{W}\right)$. In the cases where salmon were caught by jigger as by-catch of the cod fishery, they may have been feeding deep in the water column or were caught as the jigger was pulled up near the surface. In 1964 and 1966, the first two recaptures of tagged salmon were reported from Angmagssalik, both having been tagged in Europe (Carlin, 1965; Anon., 1967). Atlantic salmon were first reported from the Irminger Sea by Jensen (1967).

There are no salmon producing rivers at East Greenland due to the influence of the cold East Greenland current. Consequently, all salmon caught in that area must originate from rivers in Europe or North America, with the possibility of a few from the Kapisigdlit River in West Greenland. In the Irminger Sea, there are conditions favorable for salmon feeding because the Irminger Current, which is a branch of the Gulf Stream, forms an anti-clockwise eddy which brings warm water into the area between Iceland and Greenland, especially during summer and autumn (Templeman, 1967). A surface temperature of $4.07^{\circ} \mathrm{C}$ was recorded on 30 March 1933 in the southern part of the Irminger Sea $\left(59^{\circ} 38^{\prime} \mathrm{N}, 40^{\circ} 43^{\prime} \mathrm{W}\right.$ ) (Sverdrup et al., 1942). Temperatures around this value appear to be optimum for salmon, which, according to May (1973), perfer relatively cool surface water $\left(3^{\circ}\right.$ to $\left.6^{\circ} \mathrm{C}\right)$.

The increase in the salmon fishery at West Greenland in the mid 1960's generated much international discussion, which resulted in the establishment of the ICES/ICNAF Joint Working Party on North Atlantic Salmon to investigate the effects of the West Greenland salmon fishery on other North Atantic salmon fisheries and on the salmon spawning stocks in North American and European rivers. There was a lack of knowledge of the possible existence of salmon feeding areas in the North Atlantic outside the West Greenland area. The need for such information, in order to assess the overall exploitation rate of the salmon stocks in all feeding areas, prompted investigation of the waters off East Greenland (Jensen, MS 1973; MS 1974). The Danish research vessel Dana made four cruises to the Irminger Sea in 1966, 1973, 1974 and 1975 to study the distribution and abundance of salmon and to evaluate the significance of the area as a feeding area relative to that off West Greenland.

\section{Materials and Methods}

Most of the material used in this study was derived from drift-net fishing during four research cruises off East Greenland, where a total of 80 salmon were 


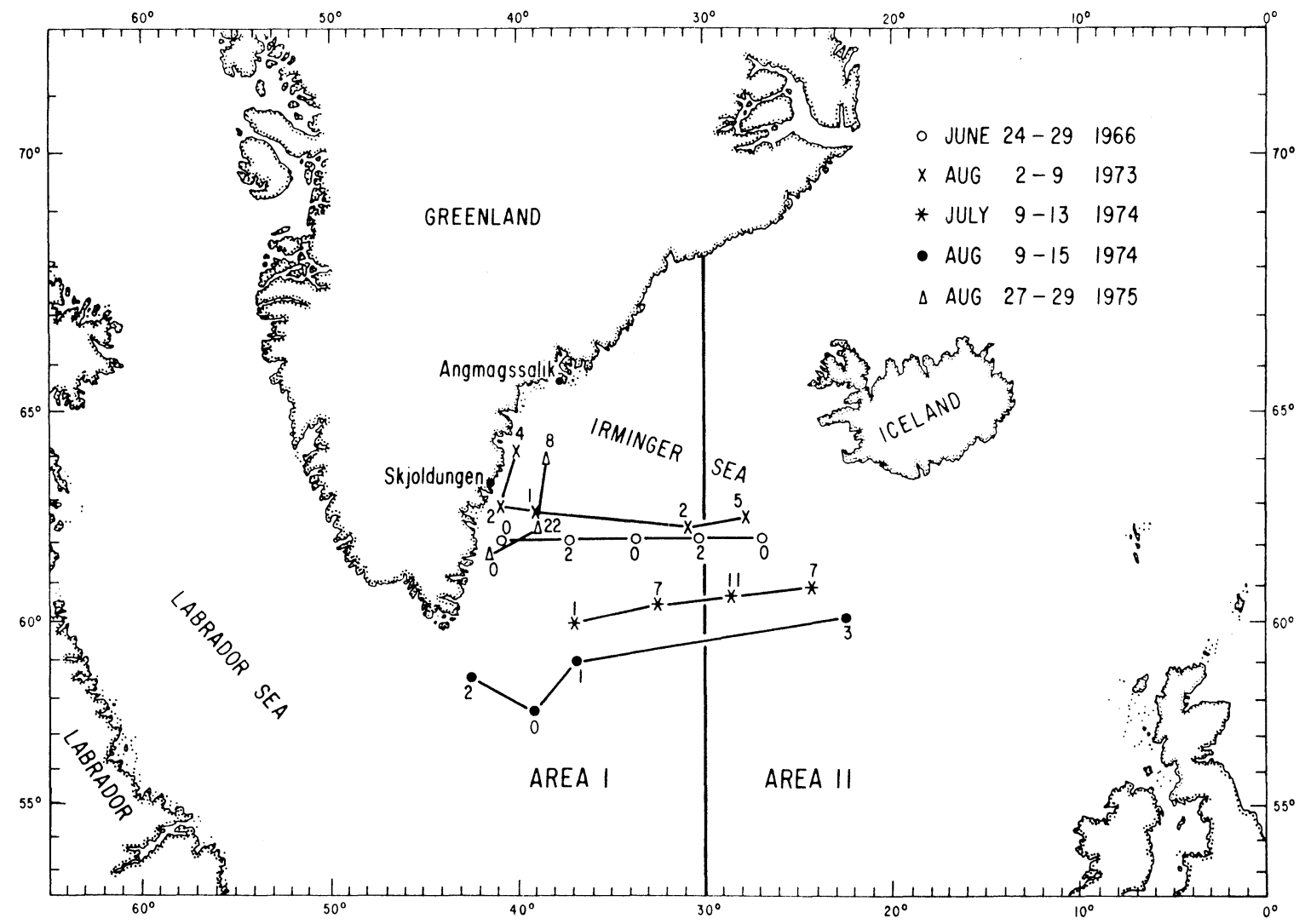

Fig. 1. Positions of salmon stations in the Irminger Sea for the R/V Dana cruises in 1966, 1973-75, and number of salmon caught per station.

caught: 4 in June 1966, 14 in August 1973, 32 in July-August 1974, and 30 in August 1975 (Fig. 1). For the purpose of this study, the Irminger Sea was divided into two sectors at $30^{\circ} \mathrm{W}$ longitude on the hypothesis that a higher proportion of the salmon taken in the eastern sector originated from European rivers by virtue of its proximity to Europe. All relevant details of drift-net fishing activity are listed in Table 1. Except for the set on 4 August 1973, all fishing was carried out at night, the nets being set just before sunset and hauled after sunrise. The duration of fishing varied between 7 and 13 hours, and the number of nets used per set varied from 35 in 1973 to $52-60$ for the remaining three cruises. The polyfilament nylon nets used in 1966 were $30 \mathrm{~m}$ long and $5 \mathrm{~m}$ deep with mesh sizes of 80,120 and $140 \mathrm{~mm}$ (stretched). The monofilament nets used in 1973-75 were $46 \mathrm{~m}$ long and 4.0 and $3.3 \mathrm{~m}$ deep for those with mesh sizes of 130 and $150 \mathrm{~mm}$ respectively.

Data for each of the salmon caught include fork length ( $\mathrm{cm}$ below), weight and sex (Appendix Table 1), and scales were collected from the left side about 3-6 scale rows above the lateral line approximately on a line extending from the posterior edge of the dorsal fin to the anterior edge of the anal fin. The stomach contents were recorded for some of the fish. Preparatory to ageing and measuring, the scales were washed and impressions of them made on plastic slides. The impressions were projected onto the ground-glass screen of a microprojector at a magnification of $30 \mathrm{X}$. Circuli were counted from the beginning of the summer zone to the end of the winter zone anteriorly along the longest axis of the scale. Broken or branched circuli were counted when they continued intact within an angle of $10^{\circ}$ on each side of the axis.

Discriminant functions for separating salmon of North American and European origin taken in the Labrador Sea and off West Greenland were developed by Lear and Sandeman (1979). The standards upon which the functions are based were derived from the scales of adult salmon which had been tagged as smolts and recaptured at West Greenland in 1968-70. The characters which yielded the best discrimination were the number of circuli in the first sea zone $\left(\mathrm{CS}_{1}\right)$ and the number in the second river zone $\left(C_{2}\right)$. The two discriminant functions used to separate the three groups of salmon (North American native, North American hatchery, and European) are:

$$
\begin{aligned}
& Y A=0.4771 C R_{2}-0.8788 C S_{1} \\
& Y B=0.7793 C R_{2}+0.6267 C S_{1}
\end{aligned}
$$


TABLE 1. Details of drift-net fishing for Atlantic salmon by the research vessel Dana in the Irminger Sea in 1966 and 1973-75. ( $P=$ polyfilament; $M=$ monofilament.)

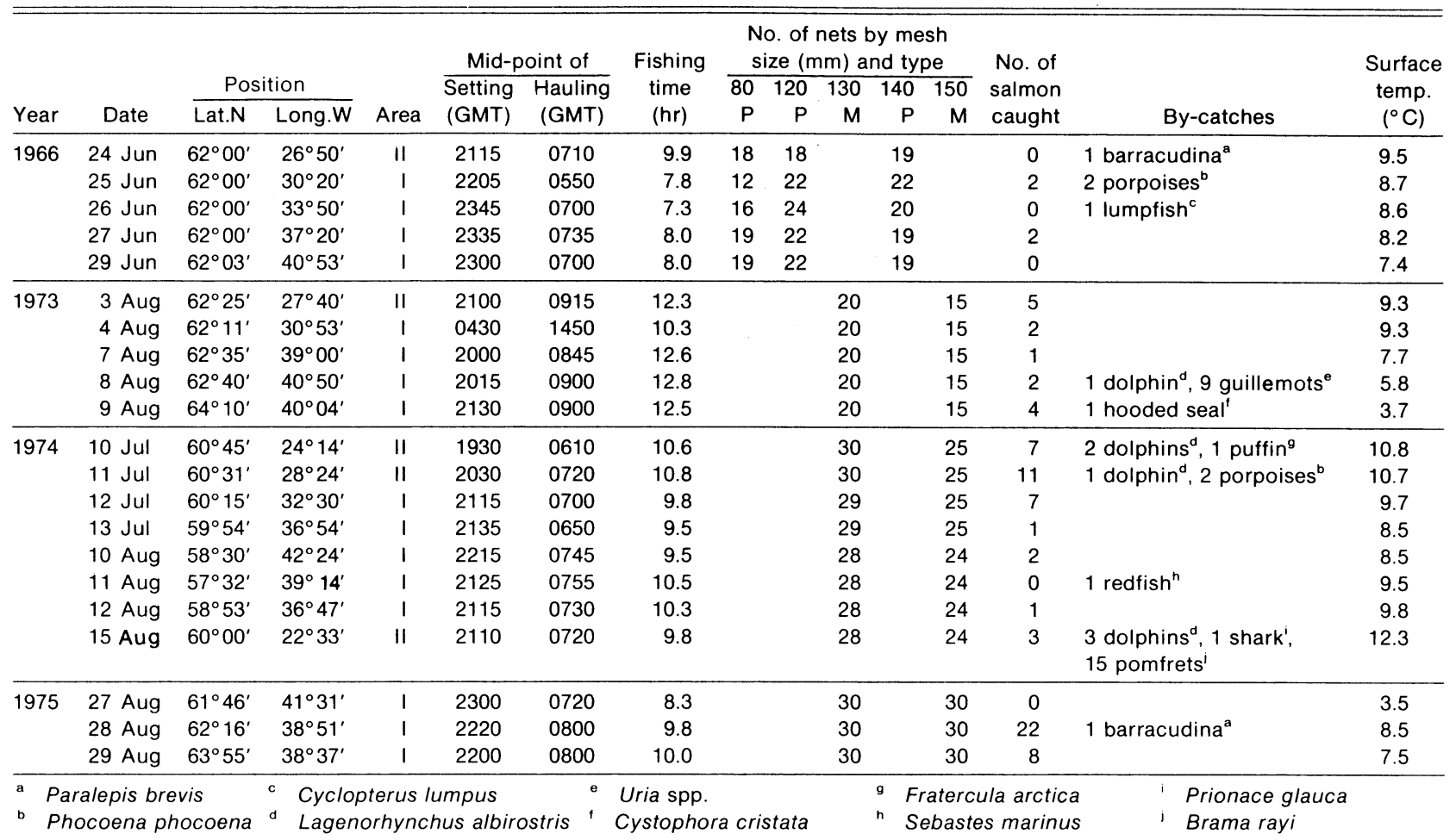

The probabilities of misclassification associated with assigning fish to the groups are as follows: North American native versus North American hatchery, 10.1\%; North American native versus European, 10.2\%; and North American hatchery versus European, 8.6\%. Because the scale character $\mathrm{CS}_{1}$ used alone exhibited a theoretical misclassification probability of $12.5 \%$, the proportions of North American and European salmon were estimated by using this character for fish of oneriver-year and for those fish of undetermined river age, i.e. all fish unable to be assigned by using the two discriminant functions based on $\mathrm{CR}_{2}$ and $\mathrm{CS}_{1}$.

The material considered in this paper also include information on very limited commercial fishing activity in the Irminger Sea in 1972 and on 24 recaptures near Angmagssalik, East Greenland, of salmon tagged in Europe and North America.

\section{Drift-net Fishing in Irminger Sea}

\section{Proportions of salmon of North American and European origin}

Of the 80 salmon caught during the four research cruises, 75 of thosen taken in 1973-75 were analyzed to determine their continental origin. None of the salmon for which scale samples were available originated from hatcheries in North America.
The proportions of salmon of North American and European origin by area and year of capture are given in Table 2. As was expected due to the proximity of Area II to Europe, there was on the average a higher percentage of European salmon in Area II (88.5\%) than

TABLE 2. Numbers and percentages of Atlantic salmon of North American (NA) and European (EU) origin caught in the Irminger Sea, 1973-75. (Area I west of $30^{\circ} \mathrm{W}$; Area ll east of $30^{\circ} \mathrm{W}$.)

\begin{tabular}{|c|c|c|c|c|c|c|c|}
\hline \multirow[b]{2}{*}{ Area } & \multirow[b]{2}{*}{ Year } & \multirow[b]{2}{*}{ Month } & \multicolumn{3}{|c|}{ No. of salmon } & \multicolumn{2}{|c|}{ Percentage } \\
\hline & & & NA & EU & Total & NA & EU \\
\hline \multirow[t]{5}{*}{1} & 1973 & Aug & 3 & 5 & 8 & 37.5 & 62.5 \\
\hline & 1974 & Jul & 2 & 6 & 8 & 25.0 & 75.0 \\
\hline & 1974 & Aug & - & 3 & 3 & - & 100.0 \\
\hline & 1975 & Aug & 8 & 22 & 30 & 26.7 & 73.3 \\
\hline & Total & & 13 & 36 & 49 & 26.5 & 73.5 \\
\hline \multirow[t]{5}{*}{ II } & 1973 & Aug & 1 & 4 & 5 & 20.0 & 80.0 \\
\hline & 1974 & Jul & 2 & 16 & 18 & 11.1 & 88.9 \\
\hline & 1974 & Aug & - & 3 & 3 & - & 100.0 \\
\hline & 1975 & Aug & - & - & - & - & - \\
\hline & Total & & 3 & 23 & 26 & 11.5 & 88.5 \\
\hline \multirow[t]{5}{*}{$1+11$} & 1973 & Aug & 4 & 9 & 13 & 30.8 & 69.2 \\
\hline & 1974 & Jul & 4 & 22 & 26 & 15.4 & 84.6 \\
\hline & 1974 & Aug & - & 6 & 6 & - & 100.0 \\
\hline & 1975 & Aug & 8 & 22 & 30 & 26.7 & 73.3 \\
\hline & Total & & 16 & 59 & 75 & 21.3 & 78.7 \\
\hline
\end{tabular}


TABLE 3. Sea and smolt age composition of Atlantic salmon of North American and European origin caught in Irminger Sea, 1973-75." (PS = previous spawners; means and standard deviations exclude numbers in parentheses.)

\begin{tabular}{|c|c|c|c|c|c|c|c|c|c|}
\hline \multirow{2}{*}{$\begin{array}{l}\text { Sea } \\
\text { age }\end{array}$} & \multirow{2}{*}{$\begin{array}{c}\text { Smolt } \\
\text { age }\end{array}$} & \multicolumn{4}{|c|}{ North American origin } & \multicolumn{4}{|c|}{ European origin } \\
\hline & & 1973 & 1974 & 1975 & Total & 1973 & 1974 & 1975 & Total \\
\hline \multirow{6}{*}{1} & 1 & - & - & - & - & 3 & 6 & 4 & 13 \\
\hline & 2 & 2 & - & 2 & 4 & 6 & 19 & 13 & 38 \\
\hline & 3 & - & 1 & - & 1 & - & 1 & 3 & 4 \\
\hline & 4 & - & 2 & 2 & 4 & - & - & - & - \\
\hline & 5 & - & 1 & 3 & 4 & - & - & 1 & 1 \\
\hline & $?$ & - & - & (1) & (1) & - & (2) & - & (2) \\
\hline \multirow[t]{2}{*}{2} & 2 & 1 & - & - & 1 & - & - & - & - \\
\hline & $?$ & - & - & - & - & - & - & (1) & (1) \\
\hline PS & 2 & 1 & - & - & 1 & - & - & - & - \\
\hline \multicolumn{2}{|c|}{ No. aged } & 4 & 4 & 7 & 15 & 9 & 26 & 21 & 56 \\
\hline \multicolumn{2}{|c|}{ Mean age (yr) } & 2.00 & 4.00 & 3.86 & 3.40 & 1.67 & 1.81 & 2.38 & 1.89 \\
\hline \multicolumn{2}{|c|}{ S. Dev. } & 0.00 & 0.82 & 1.35 & 1.30 & 0.50 & 0.49 & 0.84 & 0.68 \\
\hline \multicolumn{2}{|c|}{ Sea age 1} & 2 & 4 & 8 & 14 & 9 & 28 & 21 & 58 \\
\hline \multicolumn{2}{|c|}{ Sea age 2} & 1 & - & - & 1 & - & - & 1 & 1 \\
\hline \multicolumn{2}{|c|}{ Sea age PS } & 1 & - & - & 1 & - & - & - & - \\
\hline \multicolumn{2}{|c|}{ Total } & 4 & 4 & 8 & 16 & 9 & 28 & 22 & 59 \\
\hline
\end{tabular}

a - In addition, the four salmon caught in 1966, not identified as to continental origin, were determined to be sea age 1, with a frequency of 2,1 and 1 for smolt ages 2, 3 and 4 respectively.

in Area I (73.5\%), but the difference was not significant $\left(x^{2}=3.08, P>0.05\right)$. Because of the small sample sizes, the data are inadequate for analysis of variation between months in the different years and areas.

Although the proportions of North American and European salmon from both areas combined varied from year to year (Table 2), the differences were not significant $\left(X^{2}=2.91, \mathrm{P}>0.20\right)$. For the 3 years combined, $21 \%$ of the salmon caught originated in North American and $79 \%$ in European rivers.

\section{Age composition}

The age composition of the salmon taken in research fishing are listed by continent of origin in Table 3. One-sea-winter fish of both North American and European origin dominated the catches with 72 of the 75 salmon taken in 1973-75 and the four salmon taken in 1966 belonging to that age-group. There were two large two-sea-winter salmon and one previous spawner.

The mean smolt age varied from year to year within each continental group. For North American salmon, the mean smolt age of the 1973-75 samples was 3.4 years (range 2.00-4.00), but year to year variation was significant $\left(F_{2,12}=5.02, P<0.05\right)$. For European salmon, the corresponding mean smolt age was 1.9 years (range 1.67-2.38) with no significant year to year variation $\left(F_{2,53}=1.69, P>0.05\right)$. The average smolt age of European salmon was, however, significantly lower $(P<0.01)$ than that of North American salmon.

\section{Mean length relative to sea age, mesh size of net and origin}

The average fork length of 78 salmon of all ages taken by all nets was $66.2 \mathrm{~cm}$ (Table 4). The average

TABLE 4. Mean fork lengths of Atlantic salmon caught in the Irminger Sea in 1966 and 1973-75, by sea age, mesh size of nets and continental origin. (Nets of $120 \mathrm{~mm}$ mesh used in 1966, and 130 and $150 \mathrm{~mm}$ mesh in 1973-75).

\begin{tabular}{|c|c|c|c|c|c|}
\hline $\begin{array}{l}\text { Sea } \\
\text { age } \\
\text { (yr) }\end{array}$ & $\begin{array}{c}\text { Mesh } \\
\text { size } \\
(\mathrm{mm})\end{array}$ & Origin & $\begin{array}{l}\text { No. of } \\
\text { fish }\end{array}$ & $\begin{array}{l}\text { Mean } \\
\text { length } \\
(\mathrm{cm})\end{array}$ & $\begin{array}{c}\text { Standard } \\
\text { deviation } \\
(\mathrm{cm})\end{array}$ \\
\hline \multirow[t]{6}{*}{1} & 120 & (NK) & 4 & 54.8 & 3.77 \\
\hline & \multirow[t]{2}{*}{130} & NA & 14 & 60.6 & 4.29 \\
\hline & & EU & 41 & 66.0 & 4.54 \\
\hline & \multirow[t]{2}{*}{150} & NA & - & - & - \\
\hline & & EU & 15 & 71.0 & 4.57 \\
\hline & \multicolumn{2}{|c|}{ Total (age 1) } & $75^{\mathrm{a}}$ & 65.5 & 6.05 \\
\hline \multirow[t]{3}{*}{2} & 150 & NA & 1 & 86.0 & - \\
\hline & & EU & 1 & 84.0 & - \\
\hline & \multicolumn{2}{|c|}{ Total (age 2) } & 2 & 85.0 & 1.41 \\
\hline PS & 130 & NA & 1 & 72.0 & - \\
\hline All & 120 & All & 4 & 54.8 & 3.77 \\
\hline All & 130 & All & 56 & 64.8 & 5.06 \\
\hline All & 150 & All & $18^{\mathrm{b}}$ & 73.1 & 6.30 \\
\hline \multicolumn{3}{|c|}{ Total (all ages) } & 78 & 66.2 & 6.78 \\
\hline
\end{tabular}


TABLE 5. Sex composition of salmon of North American (NA) and European (EU) origin caught in the Irminger Sea in 1973-75 compared with those for West Greenland waters in 1974-75.

\begin{tabular}{|c|c|c|c|c|c|c|c|c|c|}
\hline \multirow[b]{2}{*}{ Year } & \multicolumn{3}{|c|}{ North American origin } & \multicolumn{3}{|c|}{ European origin } & \multicolumn{3}{|c|}{$N A+E U$} \\
\hline & Male & Female & Total & Male & Female & Total & Male & Female & Total \\
\hline \multicolumn{10}{|c|}{ Irminger Sea } \\
\hline 1973 & 2 & 2 & 4 & 4 & 5 & 9 & 6 & 7 & 13 \\
\hline 1974 & 2 & 2 & 4 & 13 & 15 & 28 & 15 & 17 & 32 \\
\hline 1975 & 1 & 7 & 8 & 6 & 16 & 22 & 7 & 23 & 30 \\
\hline Total & 5 & 11 & 16 & 23 & 36 & 59 & 28 & 47 & 75 \\
\hline Ratio(M:F) & \multicolumn{3}{|c|}{$31: 69$} & \multicolumn{3}{|c|}{$39: 61$} & \multicolumn{3}{|c|}{$37: 63$} \\
\hline \multicolumn{10}{|c|}{ West Greenland $^{\text {a }}$} \\
\hline 1973 & - & - & - & - & - & - & - & - & - \\
\hline 1974 & 24 & 148 & 172 & 88 & 251 & 339 & 112 & 399 & 511 \\
\hline 1975 & 36 & 192 & 228 & 63 & 231 & 294 & 99 & 423 & 522 \\
\hline Total & 60 & 340 & 400 & 151 & 482 & 633 & 211 & 822 & 1033 \\
\hline Ratio(M:F) & & $15: 85$ & & & $24: 76$ & & & $20: 80$ & \\
\hline
\end{tabular}

a Derived from data reported by Lear and Payne (MS 1975) and Payne et al. (MS 1976).

lengths of 75 one-sea-winter, 2 two-sea-winter and 1 previously spawned salmon were $65.5,85.0$ and 72.0 $\mathrm{cm}$ respectively. For one-sea-winter salmon taken in the $130 \mathrm{~mm}$ mesh nets, the mean length of fish of European origin $(66.0 \mathrm{~cm})$ was significantly greater $(P<0.01)$ than that of North American fish $(60.6 \mathrm{~cm})$. The mean lengths of salmon caught in nets of different mesh sizes and fiber types $(120 \mathrm{~mm}$ polyfilament, 130 and $150 \mathrm{~mm}$ monofilament) increased with mesh size (54.8, 64.8 and $73.1 \mathrm{~cm}$ respectively), the differences being highly significant $\left(F_{2,75}=26.2, P<0.01\right)$.

\section{Sex ratio}

The sex composition of the salmon taken in the research catches (Table 5) indicated that there were significantly more females than males $\left(x^{2}=4.81\right.$, $\mathrm{P}<0.05)$. However, the male:female ratios of North American (31:69) and European (39:61) salmon did not differ significantly $\left(x^{2}=0.34, P>0.50\right)$. In contrast, the samples from West Greenland waters in 1974-75 (Lear and Payne, MS 1975; Payne et al., MS 1976) for salmon of both North American and European origin contained a significantly higher proportion of females $(80 \%)$ than those from the Irminger Sea $(63 \%)$. It must be emphasized that the sizes of the Irminger Sea samples are small with highly variable sex ratios especially between 1973-74 and 1975 .

\section{Stomach contents}

Examination of the stomachs of 59 salmon taken in 1966, 1974 and 1975 showed that fish, especially Paralepis spp., and squid, Branchioteuthis riisei, were the most important food items (Table 6), both types of food being apparently common near the surface in the Irminger Sea during summer.
TABLE 6. Occurrence of food items in stomachs of salmon caught in the Irminger Sea in 1966, 1974 and 1975.

\begin{tabular}{lcccr}
\hline & \multicolumn{4}{c}{ Number of stomachs } \\
\cline { 2 - 5 } Food type & 1966 & 1974 & 1975 & Total \\
\hline Themisto gaudichaudi & 2 & - & - & 2 \\
Branchioteuthis riisei & 2 & 11 & - & 13 \\
Paralepis spp. & - & 7 & 25 & 32 \\
Fish (unidentified) & - & 2 & 5 & 7 \\
Empty & - & 5 & - & 5 \\
$\quad$ & & & & \\
$\quad$ Total & 4 & 25 & 30 & 59 \\
\hline
\end{tabular}

\section{Catch per unit effort}

Catch and effort data for the research cruises are given in Table 7, together with available information on commercial fishing activity in the Irminger Sea in September-October 1972 and commercial catch-perunit-effort data for West Greenland waters (Christensen and Lear, 1979). The standard unit of effort is based on 100 commercial nets each about $33 \mathrm{~m}$ long. A conversion factor of 0.917 was applied to convert the $30 \mathrm{~m}$ polyfilament nets used in 1966 in terms of the standard unit of effort, and a factor of 1.406 was applied to adjust the effort for the $46 \mathrm{~m}$ monofilament nets used during 1973-75. Although polyfilament nets tend to fish less efficiently than monofilament nets especially during daytime (Lear and Christensen, 1979), consideration of this factor would have very little effect on the effort applicable to the polyfilament nets used in 1966, since all sets except one were made during the night. Relative to the catch per unit effort values for commercial fishing in West Greenland waters, the catches of salmon per 100 standard nets from research and commercial fishing in the Irminger Sea were very low (Table 7), indicating a 
TABLE 7. Catch and effort for research and commercial salmon fishing in the Irminger Sea and commercial fishing at West Greenland.

\begin{tabular}{ccccccc}
\hline \hline & & \multicolumn{3}{c}{ Irminger Sea } & & W Greenland \\
\cline { 3 - 4 } Month & Year & $\begin{array}{c}\text { Catch } \\
\text { (No. of } \\
\text { salmon) }\end{array}$ & $\begin{array}{c}\text { Adjusted } \\
\text { effort } \\
\text { (nets) }\end{array}$ & $\begin{array}{c}\text { Catch } \\
\text { per 100 } \\
\text { nets }\end{array}$ & & $\begin{array}{c}\text { Catch } \\
\text { per 100 } \\
\text { nets }\end{array}$ \\
\hline Jun & 1966 & 4 & 267 & 1.5 & - \\
Aug & 1973 & 14 & 246 & 5.7 & $41^{\text {b }}$ \\
Jul & 1974 & 26 & 307 & 8.5 & 44 \\
Aug & 1974 & 6 & 292 & 2.1 & 72 \\
Aug & 1975 & 30 & 253 & 11.9 & 111 \\
Sep-Oct & $1972^{\text {a }}$ & 6 & 900 & 0.7 & $19^{\text {b }}$ \\
\hline
\end{tabular}

a Sep-Oct 1972 and all W. Greenland data from commercial fishing

b Christensen and Lear (1979); remaining three values in this column provided by Jensen (unpublished data). much smaller population in that area than at West Greenland. A comparison of research catch and effort data from the Labrador Sea (Christensen and Lear, 1979) with those from the Irminger Sea indicated lower abundance in the latter area.

\section{By-catches}

The by-catches in research fishing for salmon (Table 1) were dominated by small cetaceans, seven white-beaked dolphins Lagenorhynchus albirostris, and 4 common porpoises, Phocoena phocoena, which were common in the area, especially where the cold polar water mixes with the warm water of the Irminger Current. A hooded seal, Cystophora cristata, was caught at a station near the East Greenland coast. The

TABLE 8. List of Atlantic salmon recaptured near Angmagssalik, East Greenland, during 1966-77 from tagging in Europe and North America.

\begin{tabular}{|c|c|c|c|c|c|}
\hline \multirow{2}{*}{$\begin{array}{l}\text { Country and } \\
\text { tagging location }\end{array}$} & \multicolumn{3}{|c|}{ Release data } & \multicolumn{2}{|c|}{ Recapture } \\
\hline & Tag No. & Date & Year & Date & Year \\
\hline \multicolumn{6}{|c|}{ France } \\
\hline R. Allier, Vichy & RFb6308 & $28 \mathrm{Sep}$ & 1972 & ? Oct & 1974 \\
\hline \multicolumn{6}{|c|}{ Norway } \\
\hline R. Glomma & B335829 & 6 May & 1976 & 18 Oct & 1977 \\
\hline NW Kristiansund & N60019 & 31 May & 1976 & 26 Sep & 1977 \\
\hline \multicolumn{6}{|c|}{ Scotland } \\
\hline R. North Esk & SC5L495 & 18 May & 1965 & 22 Sep & 1966 \\
\hline R. Tummel & Y4246 & 8 May & 1976 & 30 Sep & 1977 \\
\hline \multicolumn{6}{|c|}{ Sweden } \\
\hline Lulea, Boden & $?$ & 30 May & 1962 & $1 \mathrm{Mar}$ & 1965 \\
\hline Rönneån & SV378974 & $24 \mathrm{Apr}$ & 1973 & $6 \mathrm{Nov}$ & 1974 \\
\hline Off R. Lagan & SV557533 & 3 May & 1976 & $2 \mathrm{Sep}$ & 1977 \\
\hline \multicolumn{6}{|c|}{ Canada } \\
\hline R. Madeleine, Que & D70-14299 & 12 Jun & 1970 & Autumn & 1971 \\
\hline R. La Havre, NS & 11215 & $?$ & 1973 & 19 Aug & 1974 \\
\hline R. La Havre, NS & A90243 & Oct & 1975 & $1 \mathrm{Sep}$ & 1977 \\
\hline R. La Havre, NS & A87131 & $10 \mathrm{Nov}$ & 1975 & 13 Sep & 1977 \\
\hline R. Miramichi, NB & H25332 & 20 May & 1976 & 24 Oct & 1977 \\
\hline \multicolumn{6}{|c|}{ USA } \\
\hline R. Machias, ME & B24204 & May & 1970 & 28 Sep & 1971 \\
\hline R. Penobscot, ME & B33485 & Apr-May & 1970 & 19 Sep & 1971 \\
\hline R. Penobscot, ME & B44497 & Apr-May & 1970 & 19 Sep & 1971 \\
\hline R. Penobscot, ME & B50600 & Apr-May & 1970 & 5 Oct & 1971 \\
\hline R. Penobscot, ME & B47695 & Apr-May & 1970 & 13 Oct & 1971 \\
\hline R. Penobscot, ME & B45092 & Apr-May & 1970 & 2 Oct & 1971 \\
\hline R. Penobscot, ME & B32509 & Apr-May & 1970 & ? Oct & 1971 \\
\hline R. Penobscot, ME & C69052 & Apr-May & 1973 & $?$ & 1974 \\
\hline R. Penobscot, ME & C83461 & Apr-May & 1973 & $?$ & 1974 \\
\hline R. Penobscot, ME & B59332 & Apr-May & 1973 & 7 Oct & 1974 \\
\hline R. Penobscot, ME & C86840 & Apr-May & 1973 & $?$ & 1974 \\
\hline
\end{tabular}


birds caught consisted of nine guillemots, Uria spp., and one puffin, Fratercula arctica. The fish species included one lumpfish, Cyclopterus lumpus, one redfish, Sebastes marinus, two barracudina, Paralepis spp., 15 pomfrets, Brama rayi, and one shark, Prionace glauca.

\section{Tag Recaptures at East Greenland}

Recaptures near Angmagssalik of adult salmon tagged as smolts in North America and Europe are listed in Table 8. Of the 24 tagged salmon recaptured during 1965-77, 16 were tagged as smolts in North America and 11 of these were hatchery-reared stock released in the Machias and Penobscot rivers in Maine, USA, 14-18 months prior to their recapture (E. Baum, personal communication). The 8 salmon of European origin recaptured at East Greenland were tagged as smolts in France, Norway, Scotland and Sweden.

\section{Discussion}

Analysis of scale characteristics of salmon taken in the Irminger Sea during summer indicates a mixed population of fish of North American and European origin. The age composition of the research catches showed that nearly all of these salmon had spent one winter in the sea and were destined to spend at least one more winter in the sea before returning to their home rivers in North America and Europe.

The relative proportions of salmon of North American and European origin caught in the Labrador Sea (1969-72), off West Greenland (1969-75) and in the Irminger Sea (1973-75 were different (Table 9). The proportion of North American salmon was highest in the Labrador Sea and declined from west to east, the percentage composition being $63.2,38.1$ and $21.9 \%$ respectively for North American salmon and vice versa for European salmon. However, these percentages should only be considered as indicative of a trend in view of the variation in sample size and sampling locations within each region from year to year.

The recapture at East Greenland of salmon tagged as smolts in Canada, France, Norway, Scotland, Sweden and USA indicates a mixed population in the area, but it is not possible from the recaptures to draw any firm conclusions on the likely proportions of North American and European salmon in the Irminger Sea. Recaptures of salmon tagged in the countries mentioned above and in Denmark, England, Iceland, Ireland and Spain (Jensen, 1979) were also reported from West Greenland waters, and it is likely that salmon originating in those latter countries also occur in the Irminger Sea.

From research and commercial fishing, salmon were found to occur in the Irminger Sea from June to October, but it is not possible to estimate the size of the population feeding there from the available data. Although the total area of the Irminger Sea is quite large relative to the feeding grounds off West Greenland, the actual area suitable for feeding may be considerably less than the total area. Irrespective of the size of the overall feeding area, the catch-per-uniteffort data (Table 7) indicate a much lower density and consequently a much smaller feeding population in the Irminger Sea than off West Greenland, where the stock size in 1972 was estimated to have been about 2 million salmon (Horsted et al., 1979; Jensen, 1979).

The salmon fishery in the Angmagssalik area of East Greenland is generally restricted and in some years completely prevented by drifting polar ice. Prior to the prohibition of offshore salmon fishing off West Greenland, Danish vessels en route to Greenland have occasionally attempted drift-netting for salmon in the

TABLE 9. Percentages of salmon of North American (NA) and European (EU) origin estimated from discriminant function based on scale characters reported for salmon caught in the Irminger Sea, West Greenland waters and Labrador Sea, 1969-75.

\begin{tabular}{|c|c|c|c|c|c|c|c|c|c|}
\hline \multirow[b]{2}{*}{ Year } & \multicolumn{3}{|c|}{ Irminger Sea } & \multicolumn{3}{|c|}{ West Greenland $^{a}$} & \multicolumn{3}{|c|}{ Labrador Sea $^{\mathrm{a}}$} \\
\hline & No. & NA & EU & No. & NA & EU & No. & NA & EU \\
\hline 1969 & - & - & - & 212 & 50.5 & 49.5 & 8 & 50.0 & 50.0 \\
\hline 1970 & - & - & - & 128 & 34.4 & 65.6 & 31 & 35.5 & 64.5 \\
\hline 1971 & - & - & - & 246 & 34.6 & 65.4 & 41 & 43.9 & 56.1 \\
\hline 1972 & - & - & - & 3488 & 35.7 & 64.3 & 151 & 74.8 & 25.2 \\
\hline 1973 & 13 & 30.8 & 69.2 & 113 & 45.1 & 54.9 & - & - & - \\
\hline 1974 & 32 & 12.5 & 87.5 & 834 & 42.4 & 57.6 & - & - & - \\
\hline 1975 & 30 & 26.7 & 73.3 & 522 & 43.7 & 56.3 & - & - & - \\
\hline Total & 75 & 21.3 & 78.7 & 5543 & 38.1 & 61.9 & 231 & 63.2 & 36.8 \\
\hline
\end{tabular}

a Based on data reported by Lear and Payne (MS 1975), Payne et al. (MS 1976), and Lear and Sandeman (1979). except 1973 West Greenland data by Lear (unpublished). 
Irminger Sea, but their ventures have been unsuccessful commercially (e.g. only six salmon were taken in 900 drift nets in 1972), again indicative of a small population in the area. The highest catch of salmon in the Angmagssalik district was about 10 metric tons in 1971 and about 7-8 tons were taken in 1977 , most of which are consumed locally.

\section{Acknowledgements}

The authors acknowledge the assistance and cooperation of those salmon biologists in Canada, France, Norway, Scotland, Sweden, and the USA who kindly provided information on the salmon tagged as smolts in home waters and recaptured at East Greenland. The assistance of various people of the Greenland Fisheries Investigations, both in Greenland and Denmark, is also kindly acknowledged. Mr R. F. Burfitt of the Northwest Atlantic Fisheries Center, St. John's, Newfoundland, read the scale ages and counted the circuli.

\section{References}

ANON. 1967. Fisheries of Scotland, report for 1966. Scot. Dept. Agric. Fish., $148 \mathrm{p}$.

CARLIN, B. 1965. Ostersjölax fångad vid Grönland. Svensk Fisk. Tidskr., 74(7/8): 113-114.

CHRISTENSEN, O., and W. H. LEAR. 1979. Distribution and abundance of Atlantic salmon at West Greenland. ICES Rapp. Procès-Verb., 176: 22-35.
HORSTED, Sv. Aa., J. MØLLER JENSEN, and K. P. ANDERSEN. 1979 Estimation of some important population parameters based on analysis of recaptures from the salmon tagging experiment at West Greenland, 1972. ICES Rapp. Procès-Verb., 176: 136-141.

JENSEN, J. M $\varnothing$ LLER. 1967. Atlantic salmon caught in the Irminger Sea. J. Fish. Res. Bd. Canada, 24(12): 2639-2640.

MS 1973. Salmon survey in the Irminger Sea, 1973. ICES, C. M. 1973. Doc. No. M:27.

MS 1974. Salmon survey in the southern part of the Irminger Sea. 1974. ICES, C. M. 1974, Doc. No. M:29.

1979. Recaptures of salmon at West Greenland tagged as smolts outside Greenland waters. ICES Rapp. Procès-Verb., 176: 114-121.

LEAR, W. H., and O. CHRISTENSEN. 1979. Selectivity and relative efficiency of salmon drift nets. ICES Rapp. Procès-Verb., 176: 36-42.

LEAR, W. H., and R. H. PAYNE. MS 1975. A comparison of scale analysis and serum electrophoresis as methods of determining the stock composition of Atlantic salmon off West Greenland in 1974. ICES, C. M. 1975, Doc. No. M:5.

LEAR, W. H., and E. J. SANDEMAN. 1979. Use of scale characters and discriminant functions for identifying continental origin of Atlantic salmon. ICES Rapp. Procès-Verb., 176: 68-75.

MAY, A. W. 1973. Distribution and migrations of salmon in the Northwest Atlantic. Int. Atlant. Salmon Found., Spec. Publ., 4(1): 373-382.

NIELSEN, J. 1961. Contribution to the biology of the Salmonidae in Greenland. Medd. Grønland, 159(8), 75 p.

PAYNE, R. H., W. H. LEAR, and J. MØLLER JENSEN. MS 1976. The stock composition of Atlantic salmon off West Greenland in 1975 ICES, C. M. 1976, Doc. No. M:8.

SVERDRUP, H. U., M. W. JOHNSON, and R. H. FLEMING. 1942. The Oceans, their physics, chemistry and general biology. PrenticeHall Inc., New York, $1087 \mathrm{p}$.

TEMPLEMAN, W. 1967. Atlantic salmon from the Labrador Sea and off West Greenland taken during A. T. Cameron cruise, July-August 1965. ICNAF Res. Bull. No. 4: 5-40. 
APPENDIX

TABLE 1. Length, weight, sex and age of Atlantic salmon caught with drift-nets in the Irminger Sea, 1966 and 1973-75. (Origin of salmon based on analysis of scales: EU = Europe, NA = North America.)

\begin{tabular}{|c|c|c|c|c|c|c|c|c|c|}
\hline $\begin{array}{l}\text { Ref. } \\
\text { No. }\end{array}$ & Month & Area & $\begin{array}{l}\text { Mesh } \\
\text { size } \\
(\mathrm{mm})\end{array}$ & $\begin{array}{l}\text { Fork } \\
\text { length } \\
(\mathrm{cm})\end{array}$ & $\begin{array}{c}\text { Round } \\
\text { weight } \\
\text { (kg) }\end{array}$ & Sex & $\begin{array}{c}\text { Smolt } \\
\text { age }\end{array}$ & $\begin{array}{l}\text { Sea } \\
\text { age }\end{array}$ & Origin \\
\hline $66 / 1$ & Jun & II & 120 & 52 & 1.35 & $\mathrm{~F}$ & 1 & 1 & - \\
\hline 2 & Jun & 11 & 120 & 52 & 1.45 & $M$ & 1 & 1 & - \\
\hline 3 & Jun & 1 & 120 & 60 & 2.10 & $M$ & 2 & 1 & - \\
\hline 4 & Jun & 1 & 120 & 55 & 1.65 & $\mathrm{~F}$ & 3 & 1 & - \\
\hline $73 / 1$ & Aug & 11 & 150 & 74 & 5.00 & $\mathrm{~F}$ & 1 & 1 & EU \\
\hline 2 & Aug & II & 130 & 71 & 4.10 & $\mathrm{~F}$ & 2 & 1 & EU \\
\hline 3 & Aug & II & 150 & 69 & 4.20 & $\mathrm{~F}$ & 2 & 1 & EU \\
\hline 4 & Aug & II & 130 & 74 & 5.00 & $M$ & 2 & 1 & EU \\
\hline 5 & Aug & 11 & 130 & $56^{\mathrm{a}}$ & 2.00 & $F$ & 2 & 1 & NA \\
\hline 6 & Aug & 1 & 130 & 72 & 3.60 & $M$ & 2 & $1^{b}$ & NA \\
\hline 7 & Aug & 1 & 150 & 76 & 5.00 & $M$ & - & - & - \\
\hline 8 & Aug & 1 & 150 & 86 & 8.50 & $F$ & 2 & 2 & NA \\
\hline 9 & Aug & 1 & 130 & 64 & 2.75 & $M$ & 1 & 1 & EU \\
\hline 10 & Aug & 1 & 130 & 65 & 2.80 & $\mathrm{~F}$ & 1 & 1 & EU \\
\hline 11 & Aug & 1 & 150 & 70 & 4.00 & $M$ & 2 & 1 & EU \\
\hline 12 & Aug & 1 & 130 & 67 & 3.10 & $M$ & 2 & 1 & EU \\
\hline 13 & Aug & 1 & 130 & 66 & 2.90 & $F$ & 2 & 1 & $E U$ \\
\hline 14 & Aug & 1 & 130 & 58 & 1.70 & $F$ & 2 & 1 & NA \\
\hline $74 / 1$ & Jul & 11 & 130 & 67 & 3.80 & $\mathrm{~F}$ & 2 & 1 & EU \\
\hline 2 & Jul & 11 & 130 & 65 & 2.95 & $M$ & 3 & 1 & NA \\
\hline 3 & Jul & 11 & 130 & 68 & 3.80 & $\mathrm{~F}$ & 1 & 1 & $E U$ \\
\hline 4 & Jul & 11 & 130 & 65 & 3.95 & $M$ & 2 & 1 & EU \\
\hline 5 & Jul & II & 130 & 65 & 3.40 & $F$ & 2 & 1 & EU \\
\hline 6 & Jul & II & 130 & 68 & 4.25 & $F$ & 2 & 1 & EU \\
\hline 7 & Jul & II & 130 & - & - & $\mathrm{F}$ & 2 & 1 & EU \\
\hline 8 & Jul & 11 & 150 & 64 & 3.75 & $F$ & 1 & 1 & EU \\
\hline 9 & Jul & 11 & 130 & 67 & 3.80 & $F$ & 2 & 1 & EU \\
\hline 10 & Jul & 11 & 130 & 60 & 2.75 & $M$ & 2 & 1 & EU \\
\hline 11 & Jul & II & 130 & 63 & 3.55 & $M$ & 1 & 1 & EU \\
\hline 12 & Jul & II & 130 & 54 & 1.85 & $M$ & 4 & 1 & NA \\
\hline 13 & Jul & 11 & 130 & 61 & 2.40 & $M$ & 2 & 1 & EU \\
\hline 14 & Jul & 11 & 130 & 67 & 3.90 & $M$ & 2 & 1 & EU \\
\hline 15 & Jul & II & 130 & 71 & 3.75 & $F$ & - & 1 & EU \\
\hline 16 & Jul & 11 & 150 & 64 & 3.30 & $F$ & 2 & 1 & EU \\
\hline 17 & Jul & 11 & 130 & 62 & 2.60 & $F$ & 1 & 1 & EU \\
\hline 18 & Jul & 11 & 130 & 63 & 3.25 & $F$ & 2 & 1 & EU \\
\hline 19 & Jul & 1 & 130 & 64 & 2.95 & $M$ & 1 & 1 & EU \\
\hline 20 & Jul & 1 & 130 & 61 & 2.35 & $F$ & 2 & 1 & EU \\
\hline 21 & Jul & 1 & 130 & 66 & 2.90 & $\mathrm{~F}$ & 2 & 1 & EU \\
\hline 22 & Jul & 1 & 130 & 59 & 2.39 & $F$ & 5 & 1 & NA \\
\hline 23 & Jul & 1 & 130 & 66 & 2.92 & $M$ & 2 & 1 & EU \\
\hline 24 & Jul & 1 & 130 & 60 & 2.33 & $F$ & 1 & 1 & EU \\
\hline 25 & Jul & 1 & 130 & 61 & 2.31 & $F$ & 4 & 1 & NA \\
\hline 26 & Jul & 1 & 130 & 62 & 2.60 & $M$ & 3 & 1 & EU \\
\hline 27 & Aug & 1 & 130 & 64 & 2.95 & $F$ & 2 & 1 & EU \\
\hline 28 & Aug & 1 & 130 & 59 & 3.18 & $M$ & 2 & 1 & EU \\
\hline 29 & Aug & 1 & 130 & 77 & 4.65 & $M$ & 2 & 1 & EU \\
\hline 30 & Aug & II & - & 73 & 6.00 & $M$ & 2 & 1 & EU \\
\hline 31 & Aug & II & 150 & 78 & 6.50 & $M$ & - & 1 & EU \\
\hline 32 & Aug & II & 130 & 81 & 6.75 & $M$ & 2 & 1 & EU \\
\hline
\end{tabular}


TABLE 1. (continued).

\begin{tabular}{|c|c|c|c|c|c|c|c|c|c|}
\hline $\begin{array}{l}\text { Ref. } \\
\text { No. } \\
\end{array}$ & Month & Area & $\begin{array}{c}\text { Mesh } \\
\text { size } \\
(\mathrm{mm})\end{array}$ & $\begin{array}{l}\text { Fork } \\
\text { length } \\
(\mathrm{cm})\end{array}$ & $\begin{array}{c}\text { Round } \\
\text { weight } \\
\text { (kg) }\end{array}$ & Sex & $\begin{array}{c}\text { Smolt } \\
\text { age }\end{array}$ & $\begin{array}{l}\text { Sea } \\
\text { age }\end{array}$ & Origin \\
\hline $75 / 1$ & Aug & 1 & 130 & 59 & 2.40 & $\mathrm{~F}$ & 2 & 1 & EU \\
\hline 2 & Aug & 1 & 130 & 64 & 2.30 & $\mathrm{~F}$ & 5 & 1 & NA \\
\hline 3 & Aug & 1 & 130 & 60 & 2.40 & $F$ & 4 & 1 & NA \\
\hline 4 & Aug & 1 & 130 & 66 & 3.00 & $\mathrm{~F}$ & 1 & 1 & EU \\
\hline 5 & Aug & 1 & 130 & 57 & 2.10 & $F$ & 4 & 1 & NA \\
\hline 6 & Aug & 1 & 130 & 64 & 2.90 & $F$ & 5 & 1 & NA \\
\hline 7 & Aug & 1 & 130 & 58 & 1.90 & $F$ & 2 & 1 & NA \\
\hline 8 & Aug & 1 & 130 & 64 & 2.90 & $F$ & 2 & 1 & EU \\
\hline 9 & Aug & 1 & 130 & 68 & 3.00 & $\mathrm{~F}$ & 2 & 1 & NA \\
\hline 10 & Aug & 1 & 130 & 66 & 3.10 & $F$ & 2 & 1 & EU \\
\hline 11 & Aug & 1 & 130 & 68 & 3.40 & $F$ & 2 & 1 & EU \\
\hline 12 & Aug & 1 & 130 & 68 & 3.20 & $\mathrm{~F}$ & 1 & 1 & EU \\
\hline 13 & Aug & 1 & 130 & 71 & 3.50 & $M$ & 2 & 1 & EU \\
\hline 14 & Aug & 1 & 130 & 66 & 3.50 & $F$ & 2 & 1 & EU \\
\hline 15 & Aug & 1 & 130 & 58 & 2.10 & $F$ & 5 & 1 & NA \\
\hline 16 & Aug & 1 & 130 & 67 & 3.10 & $F$ & 2 & 1 & EU \\
\hline 17 & Aug & 1 & 150 & 75 & 4.60 & $M$ & 2 & 1 & EU \\
\hline 18 & Aug & 1 & 150 & 72 & 4.00 & $F$ & 2 & 1 & EU \\
\hline 19 & Aug & 1 & 150 & 72 & 3.70 & $M$ & 1 & 1 & EU \\
\hline 20 & Aug & $i$ & 150 & 70 & 3.70 & $\mathrm{~F}$ & 2 & 1 & EU \\
\hline 21 & Aug & 1 & 150 & 78 & 7.25 & $M$ & 1 & 1 & EU \\
\hline 22 & Aug & 1 & 150 & 74 & 4.20 & $M$ & 3 & 1 & EU \\
\hline 23 & Aug & 1 & 130 & 67 & 2.70 & $M$ & - & 1 & NA \\
\hline 24 & Aug & 1 & 130 & 65 & 3.20 & $\mathrm{~F}$ & 2 & 1 & EU \\
\hline 25 & Aug & 1 & 130 & 69 & 3.20 & $F$ & 2 & 1 & EU \\
\hline 26 & Aug & 1 & 130 & 63 & 2.80 & $\mathrm{~F}$ & 2 & 1 & EU \\
\hline 27 & Aug & 1 & 150 & 64 & 3.20 & $F$ & 3 & 1 & EU \\
\hline 28 & Aug & 1 & 150 & 84 & 7.25 & $F$ & - & 2 & EU \\
\hline 29 & Aug & 1 & 150 & 77 & 4.50 & $M$ & 5 & 1 & EU \\
\hline 30 & Aug & 1 & 150 & 68 & 3.80 & $F$ & 3 & 1 & EU \\
\hline
\end{tabular}

a Fork estimated from total length.

b Previous spawner: one sea winter and one spawning mark. 